\title{
Environment carrying capacity and willingness to pay for bird- watching ecotourism in Kerandangan Natural Park, Lombok, Indonesia
}

\author{
I WAYAN SUANA ${ }^{1, \vartheta}$, HILMAN AHYADI ${ }^{1}$, GITO HADIPRAYITNO ${ }^{2}$, SALEH AMIN ${ }^{3}$, LALU ACHMAD TAN \\ TILAR WANGSAJATI SUKMARING KALIH ${ }^{4}$, FRANCISCUS XAVERIUS SUDARYANTO ${ }^{5}$ \\ ${ }^{1}$ Department of Biology, Faculty of Mathematics and Natural Sciences, Universitas Mataram. Jl. Majapahit No. 62, Mataram 83126, \\ Nusa Tenggara Barat, Indonesia. Tel./fax.: +62-370-646506, "email: wynsuana@unram.ac.id \\ ${ }^{2}$ Department of Biology Education, Universitas Mataram. Jl. Majapahit No. 62, Mataram 83126, Nusa Tenggara Barat, Indonesia \\ ${ }^{3}$ Ecotraveland. Jl. Prasarana Terusan 11, Mataram 83121, Nusa Tenggara Barat, Indonesia \\ ${ }^{4}$ Universitas 45 Mataram. Jl. Imam Bonjol 45, Mataram 83239, Nusa Tenggara Barat, Indonesia \\ ${ }^{5}$ Department of Biology, Faculty of Mathematics and Natural Sciences, Universitas Udayana. Jl. Raya Kampus Unud No. 9, Jimbaran, Badung 80361, \\ Bali, Indonesia
}

Manuscript received: 3 April 2020. Revision accepted: 28 April 2020.

\begin{abstract}
Suana IW, Ahyadi H, Hadiprayitno G, Amin S, Kalih LATTWS, Sudaryanto FX. 2020. Environment carrying capacity and willingness to pay for bird-watching ecotourism in Kerandangan Natural Park, Lombok, Indonesia. Biodiversitas 21: 2266-2274. Five trails of interest to bird-watchers and an observation point by the guest house of Kerandangan Natural Park (KNP) have potential to be developed as bird-watching ecotourism packages. In order to develop sustainable bird-watching ecotourism in KNP, we analyzed the environment carrying capacity and willingness to pay (WTP) for bird-watching ecotourism packages. All of the trails and an observation point in KNP were explored to determine the width and length of the trails, the visit time, as well as the soil texture and slope along the trails. Interviews with KNP managers and secondary data from Meteorology, Climatology and Geophysics Council (BMKG)Climatology Station Class I-West Lombok were also used to determine the status of biophysical habitats. The environment carrying capacity was calculated by combining the physical carrying capacity, real carrying capacity, and effective carrying capacity. The results show that environment carrying capacity of bird-watching ecotourism packages in KNP was higher than the actual visitation levels. It indicates that opportunity to develop and increase the number of visitors is considerable. WTP was determined by Contingent Valuation Method (CVM) with payment card approach. Through the brochure, 150 respondents were given information on bird-watching ecotourism packages, then are offered three options, and only allowed to choose one that can be paid. Data were collected by the incidental sampling method. The results show that the visitors are willing to pay for bird-watching ecotourism packages, with mean WTP of US\$ 20.7 per visitor. It implies that they are willing to shoulder the financial support for management and conservation of birds and their habitat in KNP. The findings provide important information for KNP managers for planning and marketing bird-watching ecotourism in KNP.
\end{abstract}

Keywords: Bird-watching ecotourism, physical carrying capacity, real carrying capacity, effective carrying capacity, willingness to pay

\section{INTRODUCTION}

Fifty species of birds have been recorded at Kerandangan Natural Park (KNP), Lombok, Indonesia (Suana et al. 2016). Particular attractions in KNP include Elegant Pitta (Pitta elegans), an endemic Wallacean species, which is a world favorite for bird-watchers. Since 2012, based on the guest book at KNP guest house, many international visitors from Singapore, Malaysia, Thailand, Netherlands, Switzerland, and United Kingdom had come just to find this bird. Clearly, the presence of Elegant Pitta has a tremendous appeal. The Rinjani Scops Owl (Otus jolandae), known as Lombok's endemic bird described by Sangster et al. (2013), Flores Hawk-Eagle (Nisaetus floris) are classified as Critically Endangered by BirdLife International (www.birdlife.org), Cinnamon-banded Kingfisher (Todiramphus australasia) and Rufous-chested Flycatcher (Ficedula dumetoria) are also found in KNP (Suana et al. 2016). This combination of birds can be considered the iconic species of KNP to attract birdwatchers from all over the world.
At KNP there are trails and observation points for birdwatching. Identification of the trails and observation points based on the following indicators: (i) bird diversity and endemicity; (ii) distribution and variation of bird habitat; and (iii) zonation of conservation areas, yielded five birdwatching trails and an observation point by the guesthouse (Suana et al. 2016). All of these trails have potential to be developed as bird-watching ecotourism packages.

However, tourism activities can cause various negative impacts on the environment. The high number of visitors could result in environmental disturbance in the ecotourism area. This leads to deterioration in the quality of the environment, and the environmental aesthetic value will decrease (Bunruamkaew and Muruyama 2012; EnseñatSoberanis et al. 2020; Ferreira and Harmse 2014; Marsiglio 2015; Sabokkhiz et al. 2016; Salemi et al. 2019; Sutanhaji et al. 2019). Thus, environment carrying capacity of birdwatching ecotourism packages in KNP should be analyzed to ensure its sustainability. Sustainable tourist development meets the needs of present tourists and host regions while 
protecting and enhancing opportunity for the future (Lalrosanga et al. 2019; UNEP and WTO 2005).

WTO (1981) defines the concept of carrying capacity as the maximum number of people that may visit a tourist destination at the same time, without causing destruction of the physical, economic and socio-cultural environment and an unacceptable decrease in the quality of the visitors' satisfaction. The environment carrying capacity is a useful concept in the management of wildlife and its environment (Manning 2002; Masum et al. 2019; Vujko et al. 2017). This concept refers to the number of animals that can survive in their habitat with the amount of use for recreation that can be accommodated in the park. Cifuentes (1992) has generated formula for analyzing the environment carrying capacity, by combining the physical carrying capacity (PCC), real carrying capacity (RCC), and effective carrying capacity (ECC). This has been widely used by researchers (Sayan and Atik 2011; Lagmoj et al. 2013; Lucyanti et al. 2013; Purwanto et al. 2014; Sasmita et al. 2014; Armono et al. 2017; Junaid et al. 2018; Sari et al. 2018; Wulandari et al. 2018; Maryono et al. 2019; Oktavia et al. 2019; Sofiyan et al. 2019; Zhao and Jiao 2019; Sukuryadi et al. 2020).

In general, the users of environmental goods and services such as those provided by KNP pursue their objective, regardless of environmental sustainability. The public perception that environmental goods and services have no real monetary value also causes most people to be unconcerned with environmental sustainability. Environmental services can be translated into economic value. Providing economic value to the environment is an effort to enhance the role of the community in the preservation and management of natural ecosystems (Costanza et al. 2014; Iasha et al. 2015; Paranata et al. 2017; Kalfas et al. 2020). It can also increase awareness of the importance of natural ecosystems in producing direct and indirect benefits that contribute to health, livelihood, and the economy (Cheung and Jim 2014; Abrahams 2015; Cochrane 2015; Sheridan 2015; Pengwei and Linsheng 2018).

The Contingent Valuation Method (CVM) is one method used to convert goods, services, and the convenience of environmental assets into monetary value, by directly asking people, in a survey, how much they would be willing to pay for specific environmental services (King and Mazzotta 2000). Many researchers have used CVM in their studies (Nuva et al. 2009; Kamri 2013; Cheung et al. 2014; Adamu et al. 2015; Lamsal et al. 2015; Kirkbride-Smith et al. 2016; Subanti et al. 2016; Kalfas et al. 2020; Resende et al. 2017). Willingness to pay (WTP) of the communities should be known for management and encourage investments in order to sustainable birdwatching ecotourism development at KNP.

This paper reports (i) the environment carrying capacity of bird-watching ecotourism packages, and (ii) willingness to pay by visitors for bird-watching ecotourism packages in KNP. Bird-watching is a form of ecotourism that has a bright future (UNEP 2012). Bird-watching, a popular hobby around the world, can present significant economic opportunities for countries through sustainable tourism. In the United States, at least \$ 32 billion is spent per year on bird-watching and other wildlife. In Scotland, between $\$ 8$ 12 million is spent by tourists each year, just to observe the white-tailed hawk, and $4 \%$ of job opportunity in Scotland is related to ecotourism. Opportunities to develop birdwatching ecotourism in KNP are very wide-open, so this study are expected to provide important information for KNP managers for planning and marketing bird-watching ecotourism in KNP.

\section{MATERIALS AND METHODS}

\section{Study area}

Kerandangan Natural Park (KNP), Lombok, Indonesia is a conservation area of 396.10 ha, managed by the Natural Resource Conservation Center, West Nusa Tenggara (BKSDA, NTB), Indonesia. Located in Senggigi Village, West Lombok, at $8^{\circ} 20^{\prime} 13^{\prime \prime}-8^{\circ} 20^{\prime} 15^{\prime \prime}$ and $116^{\circ} 04^{\prime} 00^{\prime \prime}-116^{\circ} 04^{\prime} 03^{\prime \prime}$ (Figure 1), KNP is a lowland monsoon forest. Based on Schmidt-Ferguson classification, the climate type is D (Wahyuni and Mildranaya 2010).

Study was carried out on five trails and observation point of bird-watching in KNP, i.e. Main Trail, Southern Valley Trail, Northern Valley Trail, Southern Hill Trail, Northern Hill Trail, also Night Birding and Bird Photography in observation point around the guesthouse (Figure 1) to calculate the environment carrying capacity of each trails. To determine the WTP, we conducted a study at three popular tourism hotspots in Lombok, i.e. Senggigi Beach, Kuta Beach, and Gili Trawangan, also nature tourists at KNP.

\section{Procedures}

Each bird-watching ecotourism packages in KNP were explored to determine the width and length of the trails, as well as the visit time. We also observed the soil texture and slope along the trails. Interviews with KNP managers and secondary data from Meteorology, Climatology, and Geophysics Council (BMKG)-Climatology Station Class IWest Lombok were also used to determine the status of biophysical habitats.

WTP was determined by CVM with payment card approach (King and Mazzotta 2000). We used payment cards approach in this study to reduce non-response rates and eliminate the need for prompting by the interviewer (Kalfas et al. 2020; Kirkbride-Smith et al. 2016; Subanti et al. 2016). Through the brochure, respondents were given information on bird-watching ecotourism packages, then are offered three options from each package and are only allowed to choose one of the payment value options that can be paid. Data were collected by the incidental sampling method, that is, by selecting respondents who are conveniently available. Our questionnaire surveys gathered data from 150 respondents. 


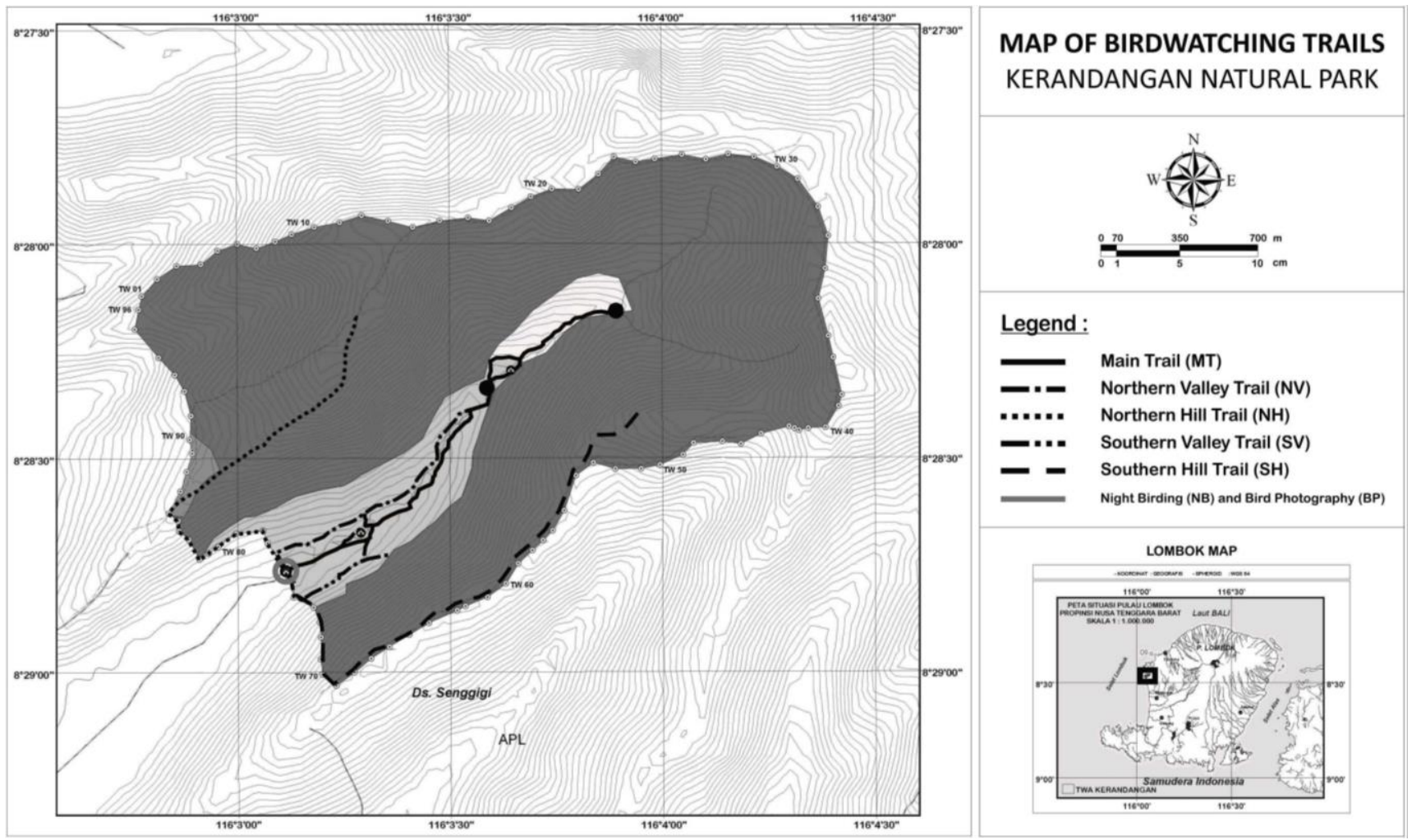

Figure 1. Map showing location of study sites in Kerandangan Natural Park, Lombok, Indonesia

\section{Data analysis}

Environment carrying capacity

Environment carrying capacity was calculated by combining the PCC, RCC, and ECC (Cifuentes 1992; Sofiyan et al. 2019). PCC is the maximum number of visitors who can physically fill an area within a certain time, expressed in the formula:

$$
\mathrm{PCC}=\frac{\mathrm{V}}{\mathrm{a}} \times \mathrm{S} \times \mathrm{t}
$$

Where:

$\frac{\mathrm{V}}{\mathrm{a}}$ : the area required by a single visitor to move freely

$\mathrm{S}$ : area available for public use

$\mathrm{t}$ : daily number of visits

$\mathrm{RCC}$ is the maximum number of visits after considering the factors that limit the occurrence of visits or correction factor $(\mathrm{CF})$. The correction factor is obtained by considering the physical, environmental, ecological, social, and management variables of the area, resulting in the formula:

$$
\mathrm{RCC}=\mathrm{PCC} \times \frac{100-\mathrm{CF} 1}{100} \times \frac{100-\mathrm{CF} 2}{100} \times \cdots \cdots \frac{100-\mathrm{CFn}}{100}
$$

Where: $\mathrm{CF}=\frac{\mathrm{Mx}}{\mathrm{Mtx}} \times 100 \%$

Mx = variable size border

Mtx $=$ number of variable sizes
ECC is the maximum number of visitors that can be accommodated by the park with the availability of management capacity (MC) by the formula:

$$
\begin{aligned}
& \mathrm{ECC}=\mathrm{RCC} \times \frac{\mathrm{MC}}{100} \\
& \text { Where: } \mathrm{MC}=\frac{\text { capacity of existing staff }}{\text { capacity of staff required }}
\end{aligned}
$$

\section{Willingness to pay}

WTP is the willingness of respondents (visitors) to pay for an environmental condition or an assessment of natural resources and natural services in order to improve the quality of the environment. The average value of respondent's WTP (EWTP) was calculated using the formula:

$$
\mathrm{EWTP}=\frac{\sum \mathrm{Wi}}{\mathrm{n}}
$$

Where:

Wi : amount of WTP that willing to be paid by respondent

i : respondent who willing to pay

$\mathrm{n}$ : number of respondents

After determining EWTP value, we calculated total value of respondent's WTP (TWTP) using the formula: TWTP $=$ EWTP $\times$ Ni, where EWTPi is average value of WTP, and Ni is total of tourist population per month. 


\section{RESULTS AND DISCUSSION}

\section{Physical carrying capacity}

There are seven bird-watching ecotourism packages at KNP analyzed in this study, i.e. Main Trail (MT), Southern Hill Trail (SH), Northern Hill Trail (NH), Southern Valley Trail (SV), Northern Valley Trail (NV), Bird Photography (BP), and Night Birding (NB). The MT, SV, and NV are relatively easy trails, so they are categorized as Soft Trail packages, while $\mathrm{SH}$ and $\mathrm{NH}$ are classified as Adventure Trail packages, because they are uphill and long trails. Bird Photography (BP) and Night Birding (NB) packages can be done in the observation point around the guest house of KNP.

Each package was calculated for its PCC value. To determine PCC value, basic criteria or assumptions are required (Cifuentes 1992). The basic assumptions for MT package were: (i) it takes a space of $1 \mathrm{~m}$ per visitor in order to move freely in the trail; (ii) MT width is $1 \mathrm{~m}$, so the total area used per visitor is $1 \mathrm{~m}^{2}$; (iii) minimum distance with other groups to avoid accumulation of visitors in the trail is $50 \mathrm{~m}$; (iv) maximum number of visitors per group is 6 , so as not to disturb the birds; (v) MT length is $1,800 \mathrm{~m}$, and the time required for the visit is 4 hours; and (vi) the KNP open from 7:00 to 17:00 hr (10 hours per day).

To find out the space available, if each visitor occupies $1 \mathrm{~m}$ in the trail, each group of 6 individuals requires $6 \mathrm{~m}$. If the distance between groups is $50 \mathrm{~m}$, then in MT $(1,800 \mathrm{~m}$ long) there are 32 groups at the same time. Thus, it needs space of 32 groups $\times 6$ visitors/group $\times 1 \mathrm{~m} /$ visitor $=192$ m.

The KNP opens 10 hours per day. It takes 4 hours to visit MT, so visitor can visit MT as much as 2.5 visits/day/visitor. Thus, the PCC for MT package is 1 visitor/m x $192 \mathrm{~m} \mathrm{x} 2.5$ visits/day $=480$ visitors/day. In the same way, the PCC of other bird-watching ecotourism packages can be determined, as presented in Table 1.
The basic assumptions for BP and NB packages were: (i) each visitor occupies a space of $1 \mathrm{~m}^{2}$ in order to move freely; (ii) there is no distance between groups; (iii) it takes two hours for each visit to BP and NB packages; (iv) the KNP opens 10 hours per day, and two additional hours from 18:00 to 20:00 hr for NB, so theoretically visitors can visit $\mathrm{BP}$ as much as 5 visits/day/visitor, and 1visit/day/visitor for $\mathrm{NB}$; and (v) the available area for each BP and NB packages are $100 \mathrm{~m}^{2}$.

Thus, PCC of BP package is 1 visitor $/ \mathrm{m}^{2} \times 100 \mathrm{~m}^{2} \times 5$ visits/day/visitor $=500$ visitors/day, while NB package is 1 $\mathrm{m}^{2} /$ visitor $\times 100 \mathrm{~m}^{2} \times 1$ visit/day/visitor $=100$ visitors/day (Table 1).

\section{Real carrying capacity}

Before calculating the RCC value, we first determined the biophysical environmental factors that limit the number of visits to the park. Based on field observation and interview with KNP manager, the biophysical environmental factors limiting the number of visits for MT, $\mathrm{SH}, \mathrm{NH}, \mathrm{SV}$, and $\mathrm{NV}$ packages are: rainfall $\left(\mathrm{CF}_{1}\right)$, erosion $\left(\mathrm{CF}_{2}\right)$, and accessibility $\left(\mathrm{CF}_{3}\right)$, while for $\mathrm{BP}$ and $\mathrm{NB}$ packages rainfall $\left(\mathrm{CF}_{1}\right)$ is the only limiting factor.

The rainfall correction factor $\left(\mathrm{CF}_{1}\right)$ is obtained by comparing the number of dry months with the number of wet months, so: $\mathrm{CF}_{1}=\frac{\sum \text { dry months }}{\sum \text { wet months }} \times 100 \%$. Referring to the climatic classification of Schmidt \& Ferguson, the categories of month based on rainfall data in the last nine years (2009 to 2017) from Meteorology, Climatology and Geophysics Council (BMKG)-Climatology Station Class IWest Lombok, are: (i) dry months (rainfall $<60 \mathrm{~mm}$ ) are 37 months; (ii) moist months (rainfall 60 to $100 \mathrm{~mm}$ ) are 7 months; and (iii) wet months (rainfall $>100 \mathrm{~mm}$ ) are 64 months. Therefore, $\mathrm{CF}_{1}$ is $(37 / 64) \times 100 \%=58 \%$. Thus, the rainfall limits the number of visits to all bird-watching ecotourism packages by $58 \%$.

Table 1. Physical carrying capacity of bird-watching ecotourism packages in Kerandangan Natural Park, Lombok, Indonesia

\begin{tabular}{|c|c|c|c|c|c|c|}
\hline Package & Trail length (m) & $\begin{array}{l}\text { Space needed per } \\
\text { group-(m) }\end{array}$ & $\begin{array}{l}\text { Service time } \\
\text { per day } \\
\text { (hours) }\end{array}$ & $\begin{array}{l}\text { Visit time } \\
\text { (hours) }\end{array}$ & $\begin{array}{l}\text { Number of visits } \\
\text { (visits/days/visitors) }\end{array}$ & PCC (visits/days) \\
\hline MT & 1,800 & 192 & 10 & 4 & 2.5 & 480 \\
\hline $\mathrm{SH}$ & 2,400 & 252 & 10 & 8 & 1.3 & 315 \\
\hline $\mathrm{NH}$ & 2,100 & 222 & 10 & 8 & 1.3 & 278 \\
\hline SV & 460 & 48 & 10 & 1.5 & 6.7 & 320 \\
\hline NV & 780 & 78 & 10 & 2 & 5.0 & 390 \\
\hline Package & $\operatorname{Area}\left(\mathbf{m}^{2}\right)$ & $\begin{array}{l}\text { Space needed/ } \\
\text { visitor }\left(\mathbf{m}^{2}\right)\end{array}$ & $\begin{array}{c}\text { Service time } \\
\text { per day } \\
\text { (hours) }\end{array}$ & $\begin{array}{l}\text { Visit time } \\
\text { (hours) }\end{array}$ & $\begin{array}{l}\text { Number of visits } \\
\text { (visits/days/ visitors) }\end{array}$ & PCC (visits/days) \\
\hline BP & 100 & 1 & 10 & 2 & 5.0 & 500 \\
\hline NB & 100 & 1 & 2 & 2 & 1.0 & 100 \\
\hline Total & & & & & & 2,383 \\
\hline
\end{tabular}

Note: MT: Main Trail, SH: Southern Hill Trail, NH: Northern Hill Trail, SV: Southern Valley Trail, NV: Northern Valley Trail, BP: Bird Photography, NB: Night Birding, PCC: Physical Carrying Capacity 
Slope range and soil texture affect the vulnerability or risk of erosion on the trails which are used as bird-watching ecotourism packages. Referring to the slope range and soil texture made by Cifuentes (1992), there are three slope ranges (less than $10 \%$, between $10 \%$ and $20 \%$, and more than $20 \%$ ), and three soil textures (gravel or sand, muddy, and clay. Combination of slope range and soil texture results in three levels of erosion risk: low, medium, and high. Trail with a slope of less than $10 \%$, whatever the soil texture, has a low or no erosion risk. Soil with gravel or sand, and clay, with a slope of between $10 \%$ and $20 \%$ have a moderate risk. Muddy soils with a slope of between $10 \%$ and $20 \%$ are at high risk of erosion, as are all soil textures with a slope above $20 \%$.

Based on the combination of slope range and soil texture, the degrees of erosion of the trail are summarized in Table 2. With the criteria in Table 2, the erosion correction factor $\left(\mathrm{CF}_{2}\right)$ can be obtained by summing the trail length which has medium risk multiplied by two and high risk multiplied by three, then divided by the total trail length. The erosion correction factor for each birdwatching ecotourism package is presented in Table 3.

Accessibility is the level of difficulty of visitors walking on the trails which are used as bird-watching ecotourism packages. The flat trail has a lower difficulty level than the uphill trail. The higher slope makes level of difficulty higher too. Based on this criterion, Cifuentes (1992) determined trail difficulty level be low, medium, and high. Trails with a slope of less than $10 \%$ have low difficulty, $10 \%$ to $20 \%$ medium, and more than $20 \%$ high.

Accessibility correction factor $\left(\mathrm{CF}_{3}\right)$ is a comparison between trail lengths that have medium to high risks with total trail length. Table 4 presents the accessibility correction factor of each bird-watching ecotourism package. Based on these correction factors, the RCC of bird-watching ecotourism packages can be calculated as presented in Table 5.

\section{Effective carrying capacity}

ECC value is obtained by comparing RCC with management capacity (MC). MC is a condition in which the administration of a protected area must be able to fully comply with its functions and objectives. MC measurement is not easy, as it involves variables such as: legal support, policies, equipment, personnel, financing, infrastructure, and facilities. Some of these variables are not measurable (Cifuentes 1992).

In this study, MC is measured only from the variable number of employees. The number of employees at KNP is four persons. When we plan to develop bird-watching ecotourism, it takes at least five additional employees (a guide and tour service providers), so MC for bird-watching ecotourism packages in KNP is 0.4. Thus, ECC can be determined as presented in Table 6.

Table 2. Degree of trail erosion based on a combination of slope range and soil texture (Cifuentes 1992)

\begin{tabular}{llll}
\hline \multirow{2}{*}{ Soil texture } & \multicolumn{3}{c}{ Slope range } \\
\cline { 2 - 4 } & \multicolumn{1}{c}{$\mathbf{1 0 \%}$} & \multicolumn{1}{c}{$\mathbf{1 0}-\mathbf{2 0 \%}$} & \multicolumn{1}{c}{$\mathbf{2 0 \%}$} \\
\hline Gravel or sand & Low & Medium & High \\
Muddy & Low & High & High \\
Clay & Low & Medium & High \\
\hline
\end{tabular}

Table 4. Accessibility correction factor of bird-watching ecotourism packages in Kerandangan Natural Park, Lombok, Indonesia

\begin{tabular}{cccc}
\hline Package & $\begin{array}{c}\text { Trail length } \\
(\mathbf{m})\end{array}$ & $\begin{array}{c}\text { Trail length with } \\
\text { risk }(\mathbf{m})\end{array}$ & $\mathbf{C F}_{\mathbf{3}}(\boldsymbol{\%})$ \\
\hline MT & 1,800 & 105 & 5.8 \\
SH & 2,400 & 1,750 & 72.9 \\
NH & 2,100 & 1,500 & 71.4 \\
SV & 460 & 0 & 0.0 \\
NV & 780 & 10 & 1.3 \\
Total & 7,540 & 3,365 & 44.6 \\
\multicolumn{4}{c}{} \\
Package & Area $\left(\mathbf{m}^{2}\right)$ & Area with risk $\left(\mathbf{m}^{2}\right)$ & $\mathbf{C F}_{\mathbf{3}}(\boldsymbol{\%})$ \\
BP & 100 & 0 & 0 \\
NB & 100 & 0 & 0 \\
\hline Note: MT: Main Trail, SH: Southern Hill Trail, NH: Northern Hill \\
Trail, SV: Southern Valley Trail, NV: Northern Valley Trail, BP: \\
Bird Photography, NB: Night Birding, CF: Correction Factor
\end{tabular}

Table 3. Erosion correction factor of bird-watching ecotourism packages in Kerandangan Natural Park, Lombok, Indonesia

\begin{tabular}{|c|c|c|c|c|c|}
\hline \multirow{2}{*}{ Package } & \multirow{2}{*}{$\begin{array}{c}\text { Trail length } \\
\text { (m) }\end{array}$} & \multicolumn{2}{|c|}{ Risk degree and weight (m) } & \multirow{2}{*}{ Trail length with risk (m) } & \multirow{2}{*}{$\mathrm{CF}_{2}(\%)$} \\
\hline & & Medium $=2$ & High $=3$ & & \\
\hline MT & 1,800 & 25 & 50 & 200 & 11.1 \\
\hline SH & 2,400 & 50 & 203 & 709 & 29.5 \\
\hline $\mathrm{NH}$ & 2,100 & 207 & 87 & 675 & 32.1 \\
\hline SV & 460 & 0 & 0 & 0 & 0 \\
\hline NV & 780 & 7 & 0 & 14 & 1.8 \\
\hline Total & 7,540 & 289 & 340 & 1,598 & 21.2 \\
\hline \multirow{2}{*}{ Package } & \multirow{2}{*}{$\operatorname{Area}\left(\mathbf{m}^{2}\right)$} & \multicolumn{2}{|c|}{ Risk degree and weight $\left(\mathrm{m}^{2}\right)$} & A rea with risk $\left(\mathrm{m}^{2}\right)$ & $\mathrm{CF}_{2}(\%)$ \\
\hline & & Medium $=2$ & High $=3$ & Area witn risk $\left(m^{-}\right)$ & $\mathrm{CF}_{2}(\%)$ \\
\hline BP & 100 & 0 & 0 & 0 & 0 \\
\hline NB & 100 & 0 & 0 & 0 & 0 \\
\hline
\end{tabular}

Note: MT: Main Trail, SH: Southern Hill Trail, NH: Northern Hill Trail, SV: Southern Valley Trail, NV: Northern Valley Trail, BP: Bird Photography, NB: Night Birding, CF: Correction Factor 
Table 6. Effective carrying capacity of bird-watching ecotourism packages in Kerandangan Natural Park, Lombok, Indonesia

\begin{tabular}{lccc}
\hline Package & MC & RCC (visitors/day) & ECC (visitors/day) \\
\hline MT & 0.4 & 169 & 75 \\
SH & 0.4 & 25 & 11 \\
NH & 0.4 & 23 & 10 \\
SV & 0.4 & 134 & 60 \\
NV & 0.4 & 159 & 71 \\
BP & 0.4 & 210 & 93 \\
NB & 0.4 & 42 & 19 \\
Total & 0.4 & 437 & 175 \\
\hline
\end{tabular}

Note: MT: Main Trail, SH: Southern Hill Trail, NH: Northern Hill Trail, SV: Southern Valley Trail, NV: Northern Valley Trail, BP Bird Photography, NB: Night Birding, RCC: Real Carrying Capacity, ECC: Effective Carrying Capacity, MC: Management Capacity

\section{Willingness to pay}

Payment card CVM approach is used to analyze the value of respondent's WTP to bird-watching ecotourism packages tariff in KNP. The results are presented in Table 7. The average value of respondent's WTP (EWTP) is obtained from the multiplication of total number of respondent's WTP with the number of respondents willing to pay according to their choice, and then divided by the total number of respondents. Table 7 presents the results of EWTP. The total value of respondent's WTP (TWTP) is calculated based on the EWTP value multiplied by the total tourist population per month - average tourist in KNP from January to July 2017 was 235 visitors per month. The results are presented in Table 7.

\section{Discussion}

Study on different aspects of the environment carrying capacity in the implementation for ecotourism in National Parks and protected areas have been carried out by some researchers (Cifuentes 1992; Manning 2002; Clivaz et al. 2004; Maldonado and Montagnini 2005; Sayan and Atik 2011; Lucyanti et al. 2013; Masum et al. 2013; Purwanto et al. 2014; Sasmita et al. 2014; Sadikin et al. 2017; Vujko et al. 2017; Lalrosanga et al. 2019; Salemi et al. 2019).
Although ecotourism is more environmentally friendly activity of resource utilization compared to other uses, it still has the potential to cause disruption to resources. To increase added value, parks or protected areas require visitor management (Eagles and McColl 2002; Sabokkhiz et al. 2016; Maryono et al. 2019). The optimal capacity for visitors must be carefully determined to provide the desired biophysical and social conditions. Optimal capacity can change according to place, season, time, user behavior, facility design, pattern and level of management, and dynamic character of environmental elements (CeballosLacurảin 1996; Marsiglio 2015; Sutanhaji et al. 2019).

Table 7. Value of respondent's WTP, EWTP, and TWTP for birdwatching ecotourism packages at Kerandangan Natural Park

\begin{tabular}{|c|c|c|c|c|c|}
\hline Package & 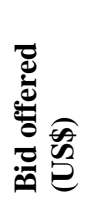 & 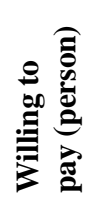 & 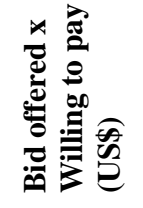 & $\stackrel{2}{\mathscr{A}}$ & $\stackrel{\mathscr{\infty}}{2}$ \\
\hline Soft Trails & 10 & 92 & 920 & & \\
\hline (MT, SV, & 20 & 44 & 880 & & \\
\hline NV) & 30 & 14 & 420 & & \\
\hline Sub total & & 150 & 2,220 & 14.8 & $3,478.0$ \\
\hline Adventure & 30 & 78 & 2,340 & & \\
\hline Trails (SH, & 40 & 57 & 2,280 & & \\
\hline $\mathrm{NH})$ & 50 & 15 & 750 & & \\
\hline Sub total & & 150 & 5,370 & 35.8 & $8,413.0$ \\
\hline Bird & 10 & 92 & 920 & & \\
\hline \multirow[t]{2}{*}{ Photography } & 20 & 39 & 780 & & \\
\hline & 30 & 19 & 570 & & \\
\hline Sub total & & 150 & 2,270 & 15.1 & $3,556.3$ \\
\hline Night & 10 & 68 & 680 & & \\
\hline \multirow{2}{*}{ Birding } & 20 & 57 & 1,140 & & \\
\hline & 30 & 25 & 750 & & \\
\hline $\begin{array}{l}\text { Sub total } \\
\text { Total }\end{array}$ & & 150 & 2,570 & 17.1 & $\begin{array}{l}4,026.3 \\
19,473.6\end{array}$ \\
\hline
\end{tabular}

Note: MT: Main Trail, SH: Southern Hill Trail, NH: Northern Hill Trail, SV: Southern Valley Trail, NV: Northern Valley Trail, WTP: Willingness to Pay, EWTP: Average Value of WTP, TWTP: Total Value of WTP

Table 5. Real carrying capacity of bird-watching ecotourism packages in Kerandangan Natural Park, Lombok, Indonesia

\begin{tabular}{|c|c|c|c|c|c|}
\hline \multirow{2}{*}{ Package } & \multirow{2}{*}{$\begin{array}{c}\text { PCC } \\
\text { (visitors/day) }\end{array}$} & \multicolumn{3}{|c|}{ Correction factor } & \multirow{2}{*}{$\begin{array}{c}\mathrm{RCC} \\
\text { (visitors/day) }\end{array}$} \\
\hline & & Rainfall & Erosion & Accessibility & \\
\hline MT & 480 & 58 & 11.1 & 5.8 & 169 \\
\hline SH & 315 & 58 & 29.5 & 72.9 & 25 \\
\hline $\mathrm{NH}$ & 278 & 58 & 32.1 & 71.4 & 23 \\
\hline SV & 320 & 58 & 0 & 0 & 134 \\
\hline $\mathrm{NV}$ & 390 & 58 & 1.8 & 1.3 & 159 \\
\hline BP & 500 & 58 & 0 & 0 & 210 \\
\hline NB & 100 & 58 & 0 & 0 & 42 \\
\hline Total & 2,383 & 58 & 21.2 & 44.6 & 437 \\
\hline
\end{tabular}

Note: MT: Main Trail, SH: Southern Hill Trail, NH: Northern Hill Trail, SV: Southern Valley Trail, NV: Northern Valley Trail, BP: Bird Photography, NB: Night Birding, PCC: Physical Carrying Capacity, RCC: Real Carrying Capacity 
The calculation of environment carrying capacity of bird-watching ecotourism packages in KNP indicates PCC $>\mathrm{RCC}>\mathrm{ECC}$ with a total value of 2,383 > 437> 175 . Based on this result, the maximum number that can be physically accommodated is 2,383 visitors per day. PCC value of 2,383 has not considered biophysical factors in the field, which means that environmental conditions of birdwatching ecotourism packages have not been used in the calculation of environment carrying capacity. Carrying capacity of the tourist environment is influenced by one of the biophysical environmental factors of the tourist area, and they have an effect on the strength or fragility of ecosystem. Ecosystem quality will decrease when the number of visitors exceeds the number of PCCs, therefore the number of visitors must be balanced with PCC in order to develop sustainable ecotourism. An area managed by the PCC approach will be able to avoid the development at too fast and of uncontrolled areas that would harm the development of ecotourism (Lucyanti et al. 2013; Lalrosanga et al. 2019; Sofiyan et al. 2019).

PCC value of bird-watching ecotourism packages associated with the actual number of visitors in KNP (235 visitors per month or only eight visitors per day) is very far below the value of PCC (2,383 visitors per day). The actual visitor value is the average number of visitors coming to KNP per month over the past seven months. This assumption does not take into account the peak season and off season, as well as the origin of the visitors (international or domestic). Peak season usually occurs during the holiday, between December to January, as well as June to July.

RCC values were obtained after including biophysical environmental factors of the tourist area limiting the number of visits, resulting in lower RCC value than PCC value. Some biophysical parameters usually used by some researchers in calculating RCC are: climatic conditions (sunlight, rainfall, snow, and wind speed); natural disasters (storms, erosion, and floods); flora and fauna (wildlife disruption, and vegetation conditions); accessibility; and temporary closure (Cifuentes 1992; Sayan and Atik 2011; Zacarias et al. 2011; Lagmoj et al. 2012; Lucyanti et al. 2013; Purwanto et al. 2014; Sasmita et al. 2014; Sofiyan et al. 2019). Based on field observation and interview with KNP manager, biophysical parameters which are considered as the limiting factors of environment carrying capacity in KNP are: rainfall, erosion, and accessibility.

Rainfall is the biggest limiting factor to RCC value, i.e. $58 \%$. Based on data from BMKG-Climatology Station Class I-West Lombok, the average rainfall is $146 \mathrm{~mm}$. January to April, and September to December are categorized as wet months with rainfall between 130 and $245 \mathrm{~mm}$. This condition makes bird observation in those months less effective, as bird activity is limited when it rains, and making it more difficult to observe. The addition of shelter or gazebo facilities scattered at several points along the trail is necessary for visitor shelter when it rains. High rainfall also increases the chances of erosion on the trail.

Erosion can limit the average number of visits by $21.2 \%$. SH and $\mathrm{NH}$ have the greatest risk of erosion, i.e.
$29.5 \%$ and $32.1 \%$ respectively. The soil texture of the KNP contains rocks, gravel, and sand, so that it is vulnerable when stepped on. This makes visitors easily slip, especially on the trail uphill. In the rainy season, the soil will be easily eroded by rainwater and cause avalanches. Trail situated on the river banks, such as MT and NV are also vulnerable to landslides due to scouring river currents. SV, BP, and NB have low or no erosion risk, because they are located in flat area.

Accessibility is level of difficulty of visitors walking on the trail, due to slope of the trail. Jangpradit (2007) ranked landform with a slope of $0-5^{\circ}$ as having high potential for ecotourism, $5-25^{\circ}$ with moderate potential, $25-35^{\circ}$ with marginal potential, and above $35^{\circ}$ without potential. Trail with a slope of more than $35^{\circ}$ has an impact on the speed and health of visitors. Fatigue of visitors due to a steep trail can disrupt the concentration of visitors during bird observation. $\mathrm{SH}$ and $\mathrm{NH}$ have a higher difficulty level compared with other packages, because some parts of the trail have a slope of $30^{\circ}$. But visitors who like hiking, $\mathrm{SH}$ and $\mathrm{NH}$ are the right choice. From the hill ridge of 450 to $650 \mathrm{~m}$ above sea level, visitors can see the beauty of the green forest cover in the valley with blue waters of Senggigi Beach in the background.

The RCC value of bird-watching ecotourism packages is 437 visitors per day, so the estimated number of visits per month that can be accommodated is 13,110 visitors. This value is far above the actual number of visitors to $\mathrm{KNP}$, which is an average of 235 visitors per month. It means that the number of visitors can be optimized up to $98.2 \%$. Taking the RCC value into consideration will help efforts to maintain the balance between environmental conditions with the number of visitors. Carrying capacity is a limitation of the use of tourism space before a significant decline in the quality of tourism resources or tourist experiences.

ECC value associated with MC shows the number of 175 visitors per day or 5,250 visitors per month. Referring to these results, the number of visitors can be optimized by $95.5 \%$ or 167 visitors per day or 5,010 visitors per month. This value indicates that with the current staffs of KNP are able to serve visitors who come every day, where the average number of visits is up to eight visitors per day. Optimizing the number of visitors based on ECC value must be accompanied by optimizing MC to $100 \%$. According to Cifuentes (1992), MC optimization takes into account variables, such as: legal basis, policies and regulations, equipment, personnel, financing, infrastructure, and facilities.

Willingness to pay by the visitors is a form of visitor responsibility to the environment. Result of visitor's WTP analysis on bird-watching ecotourism packages at KNP indicates an average value of US \$ 20.7 per visitor. All respondents in this study want to contribute to birdwatching ecotourism development at KNP. Positive responses were also obtained by Adamu et al. (2015), where $77.9 \%$ of 335 visitors interviewed were willing to pay for conservation in Yankari Game Reserve, Bauchi, Nigeria. Visitors of Gunung Gading National Park in Malaysia also showed a positive response to contribute for 
the purpose of the national park conservation (Kamri 2013). Kirkbride-Smith et al. (2016) found that user fees could provide a considerable source of income to aid reef conservation in Barbados, West Indies. Study in Gunung Gede Pangrango National Park, West Java, Indonesia by Nuva et al. (2009) found that visitors were willing to pay more for entrance fees. Interesting results found by Vujko and Gajić (2014) showed that the visitors of Fruška Gora National Park, who have not a positive attitude towards the payment of the park user fees, after persuasive communication changed their opinion and answered in favour of the payment. This indicates that persuasive communication is important to enhance participation of the communities in protecting the environment through payment of park user fees.

To conclude, the environmental carrying capacity of the bird-watching ecotourism package in KNP is higher than the actual level of visits, so the opportunity to develop and increase the number of visitors is huge. Visitors are willing to pay for bird-watching ecotourism packages with an average of US $\$ 20.7$ per visitor. Thus they are willing to shoulder financial support for the management and conservation of birds and their habitats in KNP. This finding provides important information for KNP managers for planning and marketing bird-watching ecotourism in KNP.

\section{ACKNOWLEDGEMENTS}

Our gratitude goes to Head of the Natural Resource Conservation Center, Nusa Tenggara Barat, for permission to work in Kerandangan Natural Park. Earl of Cranbrook and Yong Hoi Sen for helpful advice. Ministry of Research, Technology and Higher Education, Republic of Indonesia for the financial support grant number 074/SP2H/LT/DRPM/IV/2017.

\section{REFERENCES}

Abrahams J. 2015. Message testing nature. In: Figgis P, Mackey B, Fitzsimons J, Irving J, Clarke J (eds). Valuing Nature: Protected Areas and Ecosystem Services. Australian Committee for IUCN, Sydney.

Adamu A, Yacob MR, Hashim R. 2015. Factors determining visitors' willingness to pay for conservation in Yankari Game Reserve, Bauchi, Nigeria. Intl J Econ Manag 9: 95-114

Armono HD, Rosyid DM, Nuzula NI. 2017. Carrying capacity mode applied to coastal ecotourism of Baluran National Park, Indonesia. IOP Conf Ser Earth Environ Sci 79: 012004. DOI: 10.1088/1755$1315 / 79 / 1 / 012004$

Bunruamkaew K, Murayama Y. 2012. Land use and natural resources planning for sustainable ecotourism using GIS in Surat Thani, Thailand. Sustainability 4: 412-429. DOI: $10.3390 /$ su4030412

Ceballos-Lascuráin H. 1996. Tourism, Ecotourism and Protected Areas: The State of Nature-Based Tourism around the World and Guidelines for Its Development. IUCN, Cambridge, UK.

Cheung LTO, Fok L, Fang W. 2014. Understanding geopark visitors' preferences and willingness to pay for global geopark management and conservation. $\mathrm{J}$ Ecotourism 13: 35-51. DOI $10.1080 / 14724049.2014 .941848$

Cheung LTO, Jim CY. 2014. Expectations and willingness-to-pay for ecotourism services in Hong Kong's conservation areas. Int J Sustain Dev World Ecol 21: 149-159. DOI: 10.1080/13504509.2013.859183
Cifuentes M. 1992. Determinacion de Capacidad de Cargatruisticaen Areas Protegidas. Centro Agronomico Tropical de Investigacion Y Enzenanza Catie, Costa Rica.

Clivaz C, Hausser Y, Michelet J. 2004. Tourism monitoring system based on the concept of carrying capacity: The case of the regional natural park Pfyn-Finges (Switzerlands). Working Paper of the Finish Forest Research Institute 2, Helsinski.

Cochrane P. 2015. Natural solutions: embedding ecosystem understanding in protected area policy in Australia. In: Figgis P, Mackey B, Fitzsimons J, Irving J, Clarke J (eds). Valuing Nature: Protected Areas and Ecosystem Services. Australian Committee for IUCN, Sydney.

Costanza R, Groot R, Sutton P, van der Ploeg S, Anderson SJ, Kubiszewski I, Farber S, Turner RK. 2014. Changes in the global value of ecosystem services. Global Environ Ch 26: 152-158. DOI: 10.1016/j.gloenvcha.2014.04.002.

Eagles P, McCool S. 2002. Tourism in National Parks and Protected Areas. Cabi Publishing, Wallingford.

Enseñat-Soberanis F, Blanco-Gregory R, Mondragón-Mejía J, Simoes N, Moreno-Acevedo E, Ortega I. 2020. Crowding standards and willingness to pay at cenotes (sinkholes) of the Yucatan Peninsula: a comparative analysis of local, national and international visitors. J Ecotourism 19: 1-22. DOI: 10.1080/14724049.2019.1619747

Ferreira S, Harmse A. 2014. Kruger National Park: tourism development and issues around the management of large numbers of tourists. J Ecotourism 13: 16-34, DOI: 10.1080/14724049.2014.925907

Iasha A, Yacob MR, Kabir I, Radam A. 2015. Estimating economic value for potential ecotourism resources in Puncak Lawang Park, Agam District, West Sumatera, Indonesia. Procedia Environ Sci 30: 326331. DOI: 10.1016/j.proenv.2015.10.058

Jangpradit C. 2007. An assessment of ecotourism potential at Sauk Phet Bay at Ko Chang, Trat Province [Thesis]. Kasetsart University, Bangkok.

Junaid I, Fauziah AN. 2018. The carrying capacity for the development of marine ecotourism. Masyarakat, Kebudayaan dan Politik 31: 190-200. DOI: 10.20473/mkp.V31I22018.190-200. [Indonesian]

Kalfas DG, Zagkas DT, Dragozi EI, Zagkas TD. 2020. Estimating value of the ecosystem services in the urban and peri-urban green of a town Florina-Greece, using the CVM. Intl J Sustain Dev World Ecol. DOI: $10.1080 / 13504509.2020 .1714786$

Kamri T. 2013. Willingness to pay for conservation of natural resources in the Gunung Gading National Park, Sarawak. Procedia Soc Behav Sci 101: 506-515. DOI: 10.1016/j.sbspro.2013.07.224

King DM, Mazzotta MJ. 2000. Ecosytem valuation. www.ecosystemvaluation.org.

Kirkbride-Smith AE, Wheeler PM, Johnson ML. 2016. Artificial reefs and marine protected areas: A study in willingness to pay to access Folkestone Marine Reserve, Barbados, West Indies. PeerJ 4:e2175. DOI: $10.7717 /$ peerj. 2175

Lagmoj MA, Shokry AK, Hashemi SA, Zadegan HK. 2013. Defining the ecotourism carrying capacity of Langeroud City (case study: Khorma Forest). Greener J Soc Sci 3: 447-457.

Lalrosanga, Sajnani M, Pachuau R. 2019. Assessment of physical carrying capacity of tourism for ecological development at Phawngpui National Park, Mizoram, India. Ecology, Environ Conserv Paper 25: 837-844.

Lamsal P, Atreya K, Pant KP, Kumar L. 2015. An analysis of willingness to pay for community-based conservation activities at the Ghodaghodi Lake Complex, Nepal. Intl J Biodivers Sci Ecosyst Serv Manag 11: 341-348. DOI: 10.1080/21513732.2015.1055338

Lucyanti S, Hendrarto B, Izzati M. 2013. Assessment of carrying capacity of tourism in tourist sites of Palutungan Campsite of Mount Ciremai National Park, West Java Province. Proceedings of National Seminar on Natural Resource Management and Environment 2013. [Indonesian]

Maldonado E, Montagnini F. 2005. Carrying capacity of La Tigra National Park, Honduras: Can the park be self-sustainable? J Sustain For 19: 29-48. DOI: 10.1300/J091v19n04_03

Manning RE. 2002. How much is too much? Carrying capacity of National Parks and protected areas. In: Arnberger A, Brandenburg C, Muhar A (eds) Proceedings of monitoring and management of visitor flows in recreational and protected areas. Bodenkultur University, Vienna, Austria.

Marsiglio S. 2015. On the carrying capacity and the optimal number of visitors in tourism destinations. Tourism Economics 23: 632-646. DOI: $10.5367 /$ te. 2015.0535 
Maryono M, Effendi H, Krisanti M. 2019. Tourism carrying capacity to support beach management at Tanjung Bira, Indonesia. J Segara 15: 119-126.

Masum KM, Mamun AA, Rahman ZMM, Rahman MM, Newaz MS, Redowan M. 2013. Ecotourism carrying capacity and the potentiality of the Safari Park of Bangladesh. J For Environ Sci 29: 292-299. DOI: $10.7747 /$ JFS.2013.29.4.292

Nuva R, Shamsudin MN, Radam A, Shuib A. 2009. Willingness to pay towards the conservation of ecotourism resources at Gunung Gede Pangrango National Park, West Java, Indonesia. J Sustain Dev 2: 173 186. DOI: $10.5539 /$ jsd.v2n2p173

Oktavia RCD, Siregar H, Sunarminto T, Hermawan R. 2019. Analysis of recreational carrying capacity of urban parks and urban forests in DKI Jakarta Province. Intl J Sci Basic Appl Res 46: 38-56.

Paranata A, Sutanto H, Dakwah M. 2017. Willingness to pay of ecotourism visitors. Jurnal Ekonomi dan Kebijakan 10: 350-360. DOI: 10.15294/jejak.v10i2.11299 [indonesian]

Pengwei W, Linsheng Z. 2018. Tourist willingness to pay for protected area ecotourism resources and influencing factors at the Hulun Lake Protected Area. J Res Ecol 9: 174-180. DOI: 10.5814/j.issn.1674 764x.2018.02.007

Purwanto S, Syaufina L, Gunawan A. 2014. Potency and carrying capacity of Bukit Kelam Nature Park for ecotourism. Jurnal Pengelolaan Sumberdaya Alam dan Lingkungan 4: 119-125. [Indonesian]

Resende FM, Fernandes GW, Andrade DC, Néder HD. 2017. Economic valuation of the ecosystem services provided by a protected area in the Brazilian Cerrado: application of the contingent valuation method. Braz J Biol 77: 762-773. DOI: 10.1590/1519-6984.21215

Romadhon A, Yulianda F, Bengen D, Adrianto L. 2014. Sustainable tourism based on carrying capacity and ecological footprint at Sapeken Archipelago, Indonesia. Intl J Ecosyst 4: 190-196.

Sabokkhiz M, Sabokkhiz F, Shayesteh K, Malaz J, Shieh E. 2016. Sustainable tourism management by using recreational carrying capacity concept (Case: Mesr Desert in Iran). Rev Eur Stud 8: $105-$ 112.

Sadikin PN, Arifin HS, Pramudya B, Mulatsih S. 2017. Carrying capacity to preserve biodiversity on ecotourism in Mount Rinjani National Park, Indonesia. Biodiversitas 18: 978-989. DOI: 10.13057/biodiv/d180316

Salemi M, Jozi SA, Malmasi S, Rezaian S. 2019. Conceptual framework for evaluation of ecotourism carrying capacity for sustainable development of Karkheh protected area, Iran. Intl J Sustain Dev World Ecol 26: 354-366. DOI: 10.1080/13504509.2019.1570379

Sangster G, King BF, Verbelen P, Trainor CR.. 2013. A new owl s pecies of the Genus Otus (Aves: Strigidae) from Lombok, Indonesia. PLoS ONE 8: e53712. DOI: 10.1371/journal.pone.0053712

Sari CP, Rahayu S. 2018. Carrying capacity of Gancik Hill Top for ecotourism development in Boyolali District. E3S Web Conf. 73: 02008. DOI: $10.1051 / \mathrm{e} 3$ sconf/20187302008

Sasmita E, Darsiharjo, Rahmafitria F. 2014. Analysis of carrying capacity of tourism as an effort to support the function of conservation and tourism in Cibodas Botanical Garden, Cianjur Regency. Jurnal Manajemen Resort \& Leisure 11 (2):-. [Indonesian]

Sayan MS, Atik M. 2011. Recreation carrying capacity estimates for protected areas: Study of park. Ekoloji 20: 66-74.

Sheridan P. 2015. Public perceptions and challenges of communicating the value of ecosystems and protected areas. In: Figgis P, Mackey B,
Fitzsimons J, Irving J, Clarke J (eds). Valuing Nature: Protected Areas and Ecosystem Services. Australian Committee for IUCN, Sydney.

Sofiyan A, Hidayat W, Winarno GD, Harianto SP. 2019. Analysis of ecotourism's physical, real and effective carrying capacity in Pulau Pisang, Pesisir Barat Regency. Jurnal Sylva Lestari 7: 225-234 [Indonesian]

Suana IW, Ahyadi H, Amin S, Kalih LATTWS, Hadiprayitno G. 2016. Birdwatching in Kerandangan Natural Park, Lombok, Nusa Tenggara Barat, Indonesia. BirdingAsia 26: 8-16.

Subanti S, Hakim IM, Daerobi A, Nasir MS, Hakim AR. 2016. Determinant of willingness to pay and economic value for ecotourism object using contingent valuation method: the case of Rawapening, Semarang Regency, Central Java, Indonesia. Proceedings of the International Conference on Tourism, Gastronomy, and Tourist Destination (ICTGTD 2016). DOI: 10.2991/ictgtd-16.2017.49

Sukuryadi, Harahab N, Primyastanto M, Semedi B. 2020. Analysis of suitability and carrying capacity of mangrove ecosystem for ecotourism in Lembar Village, West Lombok District, Indonesia. Biodiversitas 21: 596-604. DOI: 10.13057/biodiv/d210222

Sutanhaji AT, Susilo A, Sunaryo S, Suyadnya IW, Ishaq B. 2019. Environmental carrying capacity base on land balance to support geotourism programs in the karst area of South Malang. J Environ Manag Tourism 10: 1756-1766. DOI: 10.14505//jemt.v10.8(40).06

UNEP [United Nation Environment Programme]. 2012. Bird-watching can help boost ecotourism industry, says UN environment agency. https://news.un.org/en/story/2012/05/410602-bird-watching-can-helpboost-ecotourism-industry-says-un-environment-agency.

UNEP [United Nations Environment Programme and World Tourism Organization]. 2005. Making tourism more sustainable: A guide for policy makers. Paris, Madrid.

Varcoe T, O'Shea HB, Eigenraam M, Jackson B. 2015. The value of Victoria'sparks: A new framework for valuation and accounting of park ecosystem services. In: Figgis P, Mackey B, Fitzsimons J, Irving J, Clarke J (eds). Valuing Nature: Protected Areas and Ecosystem Services. Australian Committee for IUCN, Sydney.

Vujko A, Gajić T. 2014. Persuasive communication and visitors willingness to pay park user fees. Turizam 18: 1-10.

Vujko A, Plavša J, Petrović MD, Radovanović M, Gajić T. 2017. Modelling of carrying capacity in National Park-Fruška Gora (Serbia) case study. Open Geosciences 9: 61-72. DOI: 10.1515/geo-2017-0005

Wahyuni TE, Mildranaya E. 2010. Guide to nature tourism in conservation area of West Nusa Tenggara. West Nusa Tenggara Natural Resources Conservation Center, Mataram. [Indonesian]

WTO [World Tourism Organization]. 1981. Saturation of tourist destinations: Report of the Secretary General.

Wulandari A, Maryono M, Setyawan A. 2018. Carrying capacity for ecotourism development in Tahura K.G.P.A.A. Mangkunagoro I. E3S Web Conf 73: 02007. DOI: 10.1051/e3sconf/20187302007

Zacarias DA, Williams AT, Newton A. 2011. Recreation carrying capacity estimations to support beach management at Praia De Faro, Portugal. Appl Geogr 31: 1075-1081. DOI: 10.1016/j.apgeog.2011.01.020

Zhao Y, Jiao L. 2019. Resources development and tourism environmental carrying capacity of ecotourism industry in Pingdingshan City, China. Ecol Process 8: 7. DOI: 10.1186/s13717-019-0161-0 